license

\title{
Menilik Tantangan Pembangunan Kesehatan di Indonesia: Faktor Penyebab Stunting di Kabupaten Jember
}

\author{
Irma Fitriana Ulfah ${ }^{1}$, Arief Budi Nugroho ${ }^{2}$ \\ i.fitriana@ub.ac.id, cakarief@ub.ac.id \\ ${ }^{1}$ Program Studi Ilmu Pemerintahan Universitas Brawijaya \\ 2 Program Studi Sosiologi Universitas Brawijaya
}

DOI https://doi.org/10.22219/sospol.v6i2.12899

\begin{abstract}
The prevalence of children under five with stunting in Indonesia is still high, namely $29.6 \%$, above the $20 \%$ limit set by WHO. In Jember Regency, the number of stunting sufferers reached 17,344 in 2018 and increased in 2019 to 19,870. The increase in the number of stunting in Jember Regency is interesting to be analyzed deeper, considering that the prevention of stunting continues to be encouraged by both the central, regional and village governments. This study analyzes the socio-economic factors that cause stunting and how local government policies address stunting. The research method used is descriptive qualitative and purposive techniques to determine informants as sources. Meanwhile, the data collection technique consisted of in-depth interviews with open-ended questions, direct observation and written documents. The results showed that the factors causing stunting were early marriage, low levels of education, work and income problems. Early marriage and lack of education cause parents to be unprepared in raising children. Work and income problems where the average informant is a farm laborer. In addition, the next problem is sanitation, where some residents do not have access to drinking water and proper sanitation. Regarding the handling of the stunting problem, the Jember Regency Government policy is relatively structured, not only running programs from the central government, the district government also has special programs related to improving health in the community, especially reducing stunting rates.
\end{abstract}

\author{
Keywords \\ Health, Jember \\ Regency, \\ Stunting, Sosio- \\ Economics, \\ SDG's
}

\section{Article History}

Received July 16, 2020

Revised August

11, 2020

Accepted August

28, 2020

Published

October 13,

2020

\begin{abstract}
Abstrak
Prevalensi balita stunting di Indonesia masih tinggi, yakni 29,6\% di atas batasan yang ditetapkan WHO sebesar 20\%. Di Kabupaten Jember jumlah penderita stunting mencapai 17.344 pada tahun 2018 dan meningkat pada tahun 2019 menjadi 19.870. Kenaikan jumlah stunting di Kabupaten Jember menjadi menarik untuk dikaji lebih dalam, mengingat pencegahan stunting terus digalakkan baik oleh pemerintah pusat, daerah maupun desa. Pemerintah Kabupataen Jember juga telah menggalakan program 1000 HPK, meskipun dalam implementasi masih menuai kendala. Penelitian ini menganalisis faktor-faktor sosial ekonomi penyebab stunting dan bagaimana kebijakan pemerintah daerah dalam penanganan stunting. Metode penelitian yang digunakan adalah deskriptif kualitatif dan teknik purposive untuk menentukan informan sebagai narasumber. Sementara, teknik pengumpulan data terdiri atas wawancara mendalam dengan format pertanyaan terbuka, observasi langsung dan dokumen tertulis. Hasil penelitian menunjukkan bahwa faktor penyebab stunting adalah pernikahan dini, tingkat pendidikan yang rendah, serta masalah pekerjaan dan pendapatan. Pernikahan dini dan rendahnya pendidikan menyebabkan ketidaksiapan orangtua dalam mengasuh anak. Masalah pekerjaan dan pendapatan dimana rata-rata informan adalah sebagai buruh tani. Selain itu, masalah berikutnya adalah masalah sanitasi, dimana beberapa warga belum memiliki akses air minum dan sanitasi yang layak. Terkait penanganan masalah stunting kebijakan Pemerintah Kabupaten Jember relatif terstruktur, bukan hanya menjalankan program dari pemerintah pusat, pemerintah kabupaten juga memiliki program khusus terkait dengan peningkatan kesehatan di masyarakat terutama menurunkan angka stunting. Bidan dan posyandu dengan kader kesehatannya menjadi ujung tombak penting untuk pengurangan stunting. Untuk kebijakan pemerintah desa di Kabupaten Jember, ada beberapa desa yang telah mengalokasikan dana desa untuk fasilitas kesehatan seperti membuat Poskesdes.
\end{abstract}

\section{Corresponding}

Author

Irma Fitriana

Ulfah. Program

Studi Ilmu

Pemerintahan

FISIP Gedung A

Lantai 1

Universitas

Brawijaya. Jalan

Veteran Kota

Malang 65145. 


\section{Pendahuluan}

Pembangunan kesehatan merupakan bagian dari pembangunan nasional, yang bertujuan untuk meningkatkan derajat kesehatan masyarakat yang optimal. Berdasarkan UUD 1945 pasal 34 ayat 3 bahwa kesehatan merupakan hak asasi dan hak dasar manusia yang harus dipenuhi dan dilindungi oleh pemerintah. Melalui UU kesehatan, pemerintah Indonesia berupaya untuk meningkatkan mutu gizi masyarakat. Jokowi telah berkomitmen dalam menurunkan tingkat kekurangan gizi pada anak yang dikenal sebagai stunting melalui strategi 5 pilar. Pilar 1 merupakan komitmen dan visi kepemimpinan yang digawangi oleh Setwapres dan TNP2K. Pilar 2 di bawah koordinasi Kominfo dan Kemeskes dalam melaksanakan kampanye nasional dan komunikasi perubahan perilaku. Pilar 3 mencakup konvergensi, koordinasi, dan konsolidasi program pusat, daerah dan desa oleh Bappenas dan Kemendagri, serta mencakup kementerian/ lembaga nasional lain. Pilar 4 mencakup gizi dan ketahanan pangan oleh Kementan dan Kemenkes. Dan terakhir pilar 5 mencakup pemantauan dan evaluasi oleh Setwapres dan TNP2K (Kemenkes RI, 2019).

Pemerintah Indoenesia telah berupaya melakukan pencegahan stunting melalui lintas sektor baik secara vertikal maupun horizontal. Secara vertikal dilakukan dengan sinkronisasi kebijakan mulai dari pemerintah pusat sampai dengan level desa. Sedangkan secara horizontal setiap level pemerintahan berkoordinasi dengan lintas bidang. Pemerintah daerah kabupaten/kota menjadi salah satu aktor kunci dalam menyusun kebijakan, program dan pembiayaan berkaitan dengan intervensi pencegahan stunting.

Adanya kebijakan pemerintah telah memberikan dampak positif dalam penurunan angka stunting. Berdasarkan Survey Kesehatan Dasar yang dilakukan oleh Kementerian Kesehatan pada tahun 2013, angka stunting di Indonesia masih berkisar di angka 37,2 \%. Pada tahun 2018, angka stunting mengalami penurunan hingga mencapai angka 30,8 \% (Kementerian Kesehatan RI Badan Penelitian dan Pengembangan Kesehatan Puslitbang Humaniora dan Manajemen Kesehatan, 2018). Namun demikian, penurunan angka stunting di Indonesia masih jauh dari target. Jika mendasarkan pada standar dari WHO terkait dengan ambang batas maksimal angka stunting yang mematok angka 20\% atau seperlima dari jumlah total anak balita, maka pencapaian penurunan angka stunting di Indonesia sampai tahun 2018 yang baru mencapai $30,8 \%$ dapat dikatakan masih jauh dari target. Selain itu, permasalahan lain yang justru menghambat percepatan penanganan stunting adalah adanya beberapa masalah lain yang berkaitan dengan anak seperti berat badan dan panjang bayi lahir yang di bawah normal dan implementasi imunisasi dasar yang justru semakin menurun (Kementerian Kesehatan RI Badan Penelitian dan Pengembangan Kesehatan Puslitbang Humaniora dan Manajemen Kesehatan, 2018).

Data prevalensi stunting di Jawa Timur sangat memprihatinkan. Angka stunting berada di atas rata-rata prevalensi stunting nasional. Terdapat 10 kabupaten dari 38 kabupaten/kota di Jawa Timur yang menjadi lokus penurunan stunting pada tahun 2018, dan meningkat menjadi 12 kab/kota pada tahun 2019, yang terdiri dari Trenggalek, Malang, Jember, Bondowoso, Probolinggo, Lamongan, Bangkalan, Sampang, Nganjuk, Pamekasan, Sumenep, dan Kediri (Kementerian Kesehatan Republik Indonesia, 2018a). Kabupaten Jember menjadi salah satu kabupaten yang menjadi sorotan dikarenakan pada tahun 2019 angka stunting justru mengalami kenaikan. Jumlah penderita stunting di Kabupaten Jember meningkat dari 17.344 pada tahun 
2018 menjadi 19.870 pada tahun 2019. Temuan penelitian yang dilakukan oleh Mayasari dari evaluasi program $1000 \mathrm{HPK}$, sebagai program pencegahan stunting masih menemui beberapa kendala. Kendala tersebut seperti tenaga pemberian pelayanan gizi dan promosi kesehatan yang masih kurang, penolakan pemberian imunisasi, rendahnya rendahnya pemberian ASI eksklusif, serta kendala pelaksanaan supervisi yang belum terjadwal (Mayasari, 2019). Sebagian besar literatur menjelaskan permasalahan stunting bukan hanya disebabkan oleh masalah kesehatan saja, tetapi juga dipengaruhi oleh masalah sosial, ekonomi, dan juga politik. Dengan demikian, penulis memetakan literatur tentang faktor-faktor penyebab stunting menjadi tiga bagian.

Pertama, faktor kesehatan. Sebuah riset di Puskesmas Limapuluh Pekanbaru menemukan dari 300 accidental sampling terdapat 25 orang balita $(33,3 \%)$ mengalami stunting, balita dengan berat badan lahir rendah sebanyak 22 orang (29,3\%) dan yang tidak diberikan ASI ekslusif sebanyak 55 orang (73,3\%) (Lidia, 2018). Faktor- faktor langsung yang mempengaruhi stunting adalah asupan makan yang tidak memadai dan penyakit infeksi atau status kesehatan anak (Pratama, Angraini, \& Nisa, 2019). Selain itu, stunting di Indonesia juga disebabkan faktor biologis dan lingkungan. Faktor biologis seperti tinggi ibu, kehamilan kurang gizi, kekurangan gizi anak, dan penyakit pada anak, sedangkan faktor lingkungan berasal dari sanitasi dan sosio ekonomi keluarga (Sakti, 2020).

Kedua, aspek kebijakan. Indonesia telah memiliki kebijakan dan regulasi penanggulangan stunting baik di tingkat pusat daerah maupun desa namun menegaskan perlunya meningkatkan sistem penanggulangan berbasis masyarakat (Nisa, 2018). Kebijakan penanggulangan stunting terkesan masih berada pada tataran menara gading. Kritik tersebut muncul karena masyarakat secara umum belum memiliki penguasaan pengetahuan yang memadai (Archda Saputri., 2019). Sementara, implementasi kebijakan intervensi gizi sensitif penurunan stunting di Kabupaten Blora belum semuanya berjalan optimal. Hal ini dikarenakan kurangnya sumber daya manusia dan anggaran, penyebaran informasi belum maksimal, kurangnya dukungan dan kesadaran masyarakat, serta data yang tidak valid (Probohastuti \& Rengga, 2019). Lebih jauh, komitmen Pemerintah Daerah Padang Pariaman terhadap masalah stunting sudah cukup baik, tetapi masih perlu peningkatan terkait anggaran, cakupan vitamin A, cakupan akses air bersih, cakupan kunjungan ibu hamil (Syafrina, Masrul, \& Firdawati, 2019). Menilik masalah stunting di luar negeri, terjadinya perbedaan spasial dan pilihan kebijakan ekonomi-politik yang diambil oleh pemerintah Afrika Selatan memberi pengaruh terhadap permasalahan stunting (Otterbach \& Rogan, 2017).

Ketiga, aspek sosial ekonomi. Pendidikan ibu yang rendah dan ayah yang tidak bekerja mendorong munculnya keluarga berpendapatan rendah yang berpotensi meningkatkan kejadian stunting pada balita (Pertiwi \& Hariansyah, Muhammad Prasetya, 2019). Indikator sosial ekonomi rumah tangga seperti pengeluaran konsumsi makanan, tingkat pendidikan ibu, status pekerjaan ibu, jumlah tanggungan keluarga, pemberian ASI, imunisasi, persalinan, sanitasi, dan penanganan sampah berpengaruh baik secara simultan maupun parsial terhadap stunting (Umar \& Haryanto, 2019).

Berdasarkan ketiga pemetaan dari penelitian terdahulu disimpulkan bahwa kajian kebijakan dan sosial ekonomi sama-sama mempunyai keterhubungan dengan stunting. Akan tetapi kajian ini masih dilakukan secara parsial dan terpisah. Oleh karena itu maka penelitian ini mencoba mengkolaborasikan kajian ekonomi politik terjadinya stunting khususnya di Jawa 
Timur. Pemaparan gagasan penulis dibagi menjadi empat bagian. Bagian pertama akan menjelaskan tentang Teori Pembangunan dan Kebijakan Kesehatan sebagai pisau analisis. Bagian kedua berisi metode penelitian. Bagian ketiga merupakan hasil dan pembahasan yang terdiri dari uraian tentang faktor penyebab stunting di Kabupaten Jember serta kebijakan pemerintah Kabupaten Jember dalam menangani masalah stunting. Bagian keempat ialah kesimpulan.

\section{Teori Pembangunan}

Pembangunan merupakan usaha untuk memajukan kehidupan masyarakat. Kemajuan di sini identik dengan kemajuan ekonomi. Akan tetapi paradigma ini menjadi semakin meluas tidak hanya bertumpu pada kemajuan ekonomi, tetapi juga berkembang pada pembangunan untuk memenuhi kebutuhan dasar manusia atau dikenal dengan Human Centered Development. Paradigma human centered development ini diartikan sebagai upaya pembangunan yang ditujukan kepada manusia melalui penciptaan kondisi atau lingkungan, baik lingkungan politik maupun budaya yang dapat mendorong lahirnya manusia yang kreatif (Budiman, 1995).

Sejalan dengan Budiman, Inkeles dan Smisth juga menegaskan pentingnya faktor manusia sebagai penopang pembangunan. Manusia perlu mengembangkan sarana material untuk menjadi manusia kreatif, oleh Inkeles disebut sebagai manusia kreatif. Salah satu cara untuk menjadi manusia kreatif tersebut adalah dengan memberikan pendidikan, pengalaman kerja, dan pengenalan media massa. Dengan pengalaman tersebut manusia dapat berubah dari manusia tradisional menjadi manusia modern (Budiman, 1995).

Menurut World Bank tujuan pembangunan adalah untuk perbaikan kesejahteraan manusia secara nyata dan berkelanjutan. World Bank juga menjelaskan tiga target pembangunan antara lain: perbaikan ekonomi, pembangunan sosial, dan pelestarian lingkungan. Perbaikan ekonomi dilakukan dalam menurunkan angka kemiskinan. Pembangunan sosial melalui program pendidikan dasar, kesetaraan gender dan pemberdayaan masyarakat, serta mengurangi angka kematian bayi melalui peningkatan pelayanan kesehatan. Terakhir, pembangunan berkelanjutan yang berwawasan lingkungan (Azahari, 2000).

Pemerintah Indonesia melalui BPS mengukur pembangunan melalui Indeks Pembangunan Manusia (IPM). IPM ditujukan untuk melihat bagaimana masyarakat dapat mengakses hasil pembangunan dalam memperoleh pendapatan, kesehatan, dan pendidikan. Secara umum IPM di Indonesia terus mengalami peningkatan, dari 70,18 pada tahun 2016 telah meningkat menjadi 70, 81 pada tahun 2019. Artinya IPM Indonesia masuk dalam kategori tinggi.

\section{Kebijakan Kesehatan}

Masalah stunting merupakan masalah global, sehingga kebijakan penanganan stunting sendiri telah menjadi komitmen global. Komitmen global dalam upaya pencegahan stunting salah satunya muncul adanya Gerakan Scaling Up Nutrition (SUN) di bawah PBB akibat tidak tercapainya sasaran Millenium Development Goals (MDGs) yang salah satu tujuannya adalah memberantas kemiskinan dan kelaparan. Indonesia bergabung dengan SUN sejak Desember 2011. MDGs sendiri telah diimplementasikan pada tahun 2000-2015 dan dilanjutkan dengan Sustainable Development Goals (SDGs) Tahun 2015-2030. Penurunan stunting merupakan salah satu target SDGs yang termasuk pada tujuan ke-2 yakni mengakhiri kelaparan dan 
termasuk didalamnya mengatasi gizi buruk. WHO menargetkan penurunkan angka stunting hingga 40\% pada tahun 2025.

Menurut WHO ada beberapa poin penting dalam mengurangi angka stunting, antara lain: pertama, perlunya intervensi dalam mengurangi stunting dan obesitas pada anak; kedua, adanya monitoring dalam pemberian layakan kesehatan secara merata; ketiga, penyediaan kondisi lingkungan yang higienis dan penyediaan air bersih, sanitasi yang layak, dan saluran air limbah yang layak; keempat, perlindungan social melalui program transfer tunai dan status gizi anak; kelima, adanya program yang menjamin ketahanan dan keragaman pangan khususnya bagi kelompok rentan; keenam, perlunya program yang bertujuan untuk meningkatkan status gizi remaja dan ibu; dan ketujuh, pentingnya keterlibatan lintas sektor baik pemerintah maupun non pemerintah (WHO, 2018).

Pemerintah Indonesia telah berkomitmen dalam menurunkan angka stunting. Sebelumnya, Indonesia juga telah mempunyai kebijakan kesehatan yang diatur dalam UU No 36 Tahun 2009. Kebijakan ini sebagai wujud untuk meningkatkan derajat kesehatan masyarakat Indonesia. Akan tetapi masalah kesehatan masih menjadi pekerjaan rumah bagi pemerintah sampai saat ini. Menurut Atmarita, beberapa masalah yang dihadapi oleh Indonesia adalah rendahnya pemberian ASI eksklusif yang belum mencapai 50\%. Selain itu, asupan anak usia $>6$ bulan sebagian cenderung mengonsumsi karbohidrat yang mencapai $95 \%$, sangat kurang dari asupan protein, buah, dan sayur, sehingga asupan gizinya tidak terpenuhi. Ditambah lagi, permasalahan lemahnya pemantauan penggunaan susu formula dan masih minimnya fasilitas ruang menyusui (Kementerian Kesehatan Republik Indonesia, 2018b).

Implementasi SDGs diselaraskan dengan nawacita Jokowi dan perencanaan pembangunan nasional melalui RPJMN tahun 2015-2019 dan ditindaklanjuti dengan Peraturan Presiden No 59 Tahun 2017. Hal ini juga ditindaklanjuti dengan adanya Program Indonesia Sehat oleh Kementerian Kesehatan melalui sasaran pembangunan kesehatan pada tahun 2015-2019 yang salah satunya melalui pembangunan gizi masyarakat khususnya untuk pengendalian angka stunting.

Kebijakan lain dalam mendukung percepatan pencegahan stunting di Indonesia, misalnya adanya UU Pangan No 18 Tahun 2012 yang diikuti dengan Gerakan Nasional Percepatan Perbaikan Gizi melalui Peraturan Presiden No 42 Tahun 2013 dan Peraturan Presiden No 83/ 2017. Selain itu, juga adanya Inpres No 1 Tahun 2017 mengenai Gerakan Masyarakat Hidup Sehat bahkan juga ada kebijakan Peraturan Menteri Desa dan PDT No 16 Tahun 2018 tentang prioritas Dana Desa yang salah satunya digunakan untuk pencegahan stunting. Kebijakan yang ada di Indonesia terutama pada level pusat telah banyak mengakomodir pencegahan stunting. Ditambah lagi kebijakan di masing-masing pemerintah daerah.

\section{Metode}

Metode penelitian ini menggunakan menggunakan metode kualitatif yang bertujuan untuk menjelaskan fenomena melalui pengumpulan data sedalam-dalamnya (Kriyantono, 2006). Penelitian kualitatif juga diartikan sebagai jenis penelitian yang temuan- temuanya tidak diperoleh melalui prosedur statistik atau bentuk hitungan lainnya (Anselm \& Juliet, 2013). Dalam penelitian 
kualitatif ini menggunakan dua jenis data yang data primer dan data sekunder. Pertama, data primer merupakan data yang langsung memberikan data kepada pengumpul data (Sugiyono, 2012). Data primer dari penelitian ini berupa hasil wawancara dan observasi lapangan (Moleong, 2013). Wawancara dilakukan dengan beberapa informan antara lain: Dwi Handarisasi Kepala Seksi Kesehatan Keluarga Gizi, dan Masyarakat Dinas Kesehatan, Dewi Nova Wahyuni, Kepala Bidang Pelayanan Kesehatan Dinas Kesehatan, Bambang Sutejo Kaur Pemerintahan Desa Kalisat, Mike Petugas Gizi Puskesmas Ledokombo, Ervan Setiawan, Kasubag Pemerintahan, Kecamatan dan Kelurahan, dan orang tua yang mempunyai anak stunting di dua desa lokasi penelitian. Penulis juga melakukan pengamatan langsung objek penelitian untuk melihat dari dekat mengenai kegiatan yang terjadi di lapangan (Riduan, 2009).

Data sekunder diperoleh peneliti melalui teknik dokumentasi (Usman \& Akbar, 2009). Dokumen yang dianalisis antara lain Hasil Utama Riskesdas 2018 Provinsi Jawa Timur, Pedoman TNP2K: Strategi Nasional Percepatan Pencegahan Stunting 2018-2024, Buku Panduan Konvergensi Program/ Kegiatan Percepatan Pencegahan Stunting (Buku Pegangan Resmi Organisasi Perangkat Daerah), Pedoman Pelaksanaan Intervensi Penurunan Stunting Terintegrasi di Kabupaten/ Kota, Kementerian PPN/ Bappenas, Petunjuk Teknis Pedoman Pelaksanaan Intervensi Penurunan Stunting Terintegrasi, Paparan Direktur Jenderal Kesehatan Masyarakat Tentang Upaya Percepatan Penurunan Stunting: Evaluasi Pelaksanaan Tahun 2018 \& Rencana Tindak Tahun 2019, berita, serta transkrip wawancara.

Setelah melakukan wawancara, observasi dan pengumpulan berbagai dokumen, langkah selanjutnya adalah melakukan analisis data. Analisis data adalah upaya yang dilakukan melalui cara bekerja dengan data, mengorganisasikan data, memilah-milahnya menjadi satuan yang dapat dikelola, mensistematisasikannya, mencari dan menemukan pola, menemukan apa yang penting dan apa yang dipelajari, dan memutuskan apa yang akan diceritakan pada orang lain (Moleong, 2009). Analisis data mencakup empat langkah, antara lain koleksi data, reduksi data, sistematisasi data dan analasis data dan penarikan kesimpulan.

\section{Hasil dan Pembahasan}

\section{Faktor Penyebab Stunting di Kabupaten Jember}

Kabupaten Jember merupakan salah satu kabupaten yang masuk lokus stunting baik tahun 2018 maupun 2019. Artinya Kabupaten Jember sudah masuk dalam prioritas percepatan penurunan stunting. Hal ini diperparah dengan naiknya angka stunting di Kabupaten Jember dari 17.344 pada tahun 2018 menjadi 19.870 pada tahun 2019. Hal ini menjadi menarik untuk mendalami bagaimana kondisi sosial ekonomi masyarakat di sana dan kebijakan penanganan stunting di Kabupaten Jember. Mengingat Jember merupakan daerah tapal kuda yang ditunjang dengan sektor pertanian.

Merujuk penelitian yang dilakukan oleh Pertiwi, dkk (2019), Umar dan Haryanto (2019) menunjukkan bahwa permasalahan social ekonomi rumah tangga beresiko menyebabkan permasalahan stunting. Akan tetapi secara umum temuan penelitian ini bahwa tren kemiskinan di Kabupaten Jember terus mengalami penurunan sedangkan kasus stunting justru mengalami peningkatan. Tingkat kemiskinan di Kabupaten Jember pada tahun 2011 sebesar 12,44 menurun menjadi 9.98 pada tahun 2018 (BPS Kabupaten Jember, 2019). Penurunan kemiskinan secara umum baik nasional maupun kemiskinan kabupaten tidak serta merta menaikkan pendapatan per 
rumah tangga. Artinya faktor ekonomi bukan menjadi faktor satu-satunya penyebab stunting di Kabupaten Jember. Oleh karena itu pembangunan tidak hanya bertumpu pada faktor ekonomi saja.

Perekonomian Kabupaten Jember lebih banyak ditunjang pada sektor pertanian, kehutanan, dan kelautan. Meskipun sektor ini tetap mendominasi dalam 5 tahun terakhir, tetapi sektor ini justru mengalami penurunan yakni dari 30,74\% pada tahun 2014 menurun menjadi $27,39 \%$. Penurunan ini diikuti dengan kenaikan pada sektor yang lain seperti perdagangan, kontruksi dan informasi, dan komunikasi. Secara detail kontribusi lapangan pekerjaan terhadap PDRB di Kabupaten Jember dapat dilihat pada tabel 1.

Tabel 1. Jenis lapangan kerja dan kontribusinya terhadap PDRB

\begin{tabular}{|c|c|c|c|}
\hline \multirow{2}{*}{ No } & \multirow{2}{*}{ Jenis lapangan Usaha } & \multirow{2}{*}{$\begin{array}{l}\text { Peranan } \\
\text { PDRB }\end{array}$} & Jumlah/Tahun \\
\hline & & & (2014-2018) \\
\hline 1 & Pertanian, kehutanan, kelautan & menurun & $\begin{array}{l}30,74 \text { menjadi } \\
27,39\end{array}$ \\
\hline 2 & Industri Pengolahan & menurun & $\begin{array}{c}19,84 \text { menjadi } \\
13,96\end{array}$ \\
\hline 3 & $\begin{array}{l}\text { Usaha perdagangan besar dan eceran, } \\
\text { reparasi mobil dan sepeda motor/ }\end{array}$ & naik & $\begin{array}{l}12,38 \text { menjadi } \\
13,96\end{array}$ \\
\hline 4 & Kontruksi & naik & 7,33 menjadi 8,09 \\
\hline 5 & Informasi dan komunikasi & naik & 5,83 menjadi 6,33 \\
\hline
\end{tabular}

Sumber: BPS Kabupaten Jember (2019)

Penelitian ini memfokuskan kajian stunting pada 2 desa yakni Desa Ledokombo dan Desa Kalisat. Masyarakat kedua desa tersebut masih mengandalkan pertanian sebagai sumber penghasilan warga desa. Dari kajian yang dilakukan pada Desa Kalisat dan Desa Ledokombo terjadi pergeseran sumber pendapatan warga desa. Pada Desa Kalisat terdapat beberapa warga yang meninggalkan sektor pertanian dan beralih kerja pada bidang lain yakni sebagai buruh migran (utamanya pada perempuan desa) ataupun buruh bangunan (utamanya pada laki-laki desa). Beberapa perempuan Desa Kalisat bekerja di Malaysia untuk memperoleh pendapatan, dan sebagian laki-laki Desa Kalisat bekerja sebagai buruh bangunan di Provinsi Bali.

Permasalahan lain yang dihadapi warga adalah ketika musim kemarau dan terjadi gagal panen. Karena berdasarkan penelusuran informan, mereka hanya sebagai buruh tani bukan pemilik lahan. Hal ini akan diperparah jika para pemilik lahan lebih memilih untuk mengolah lahannya sendiri karena tidak mampu membayar buruh tani (JH, 2019). Selain sebagai buruh tani, berdasarkan pengakuan informan, mereka juga mencari pekerjaan lain seperti ketika musim tembakau (NY, 2019). Hal ini dilakukan untuk mendapat tambahan biaya demi pemenuhan kebutuhan sehari-hari.

Berdasarkan temuan penelitian, bahwa keluarga yang mengalami kasus stunting adalah keluarga yang melakukan praktik pernikahan dini. Rata-rata perempuan menikah pada umur 18 tahun, bahkan ada yang lebih muda. Sebagian besar alasan mereka menikah muda karena alasan agama supaya tidak terjadi dosa dan karena menjadi budaya masyarakat. Praktik adanya nikah dini ini diperparah dengan tidak memadainya pengetahuan masyarakat dalam mengurus rumah tangga. Pernikahan dilakukan tanpa pertimbangan yang matang, tanpa ada perencanaan yang baik untuk kehidupan pasca pernikahan. Mereka tidak memikirkan status pekerjaan, kepemilikan 
tempat tinggal dan tidak mempertimbangkan kemampuan untuk mencukupi kebutuhan hidup sehari-hari. Keluarga dengan pernikahan dini ini, karena belum mandiri maka akan selalu meminta bantuan orangtua. Mereka tinggal bersama dengan orang tua mereka.

Rata-rata minimal tingkat pendidikan (Kalisat dan Ledokombo) dari para informan dan warga adalah Sekolah Dasar. Rendahnya rata-rata tingkat pendidikan masyarakat tersebut karena masih ada anggapan umum bahwa perempuan tidak perlu sekolah tinggi-tinggi. Faktor lain yang menyebabkan banyak perempuan tidak melanjutkan sekolah adalah karena keterbatasan biaya.

Pernikahan dini dan tingkat pendidikan yang rendah ini menambah daftar masalah penyebab stunting. Rendahnya pendidikan orang tua khususnya ibu berimpilkasi pada pola pengasuhan anak. Para informan menyampaikan tidak ada hal khusus yang dipahami terkait dengan memelihara kesehatan anak kecuali harus datang rutin ke Posyandu. Begitu pula pengetahuan dari orangtua-orangtua sebelumnya, tidak ada hal khusus terkait dengan makanan yang dapat menambah gizi dari anak balita. Orangtua dan anak yang memiliki balita terfokus pada kegiatan untuk bertahan hidup seperti mendapatkan pekerjaan tambahan penghasilan.

Solusi permasalahan tersebut jika merujuk pendapat Inkeles dan Smisth maka perlu adanya peningkatan pendidikan dan pengalaman kerja (Budiman, 1995) sehingga dapat merubah kondisi masyarakat di Kabupaten Jember. Hal ini untuk meningkatkan kondisi masyarakat dalam memutus mata rantai penyebab stunting. Karena jika permasalahan stunting ini tidak dapat terselesaikan akan membawa dampak baik jangka pendek maupun jangka panjang. Dampak jangka pendek seperti peningkatan kesakitan dan kematian; gangguan perkembangan kognitif, motorik, dan verbal pada anak, dan peningkatan biaya kesehatan. Untuk jangka panjang antara lain: postur tubuh tidak optimal, risiko obesitas dan penyakit lainnya, menurunnya kesehatan reproduksi, kemampuan belajar yang tidak optimal, serta produktivitas, dan kapasitas kerja yang tidak optimal (Kementerian Kesehatan Republik Indonesia, 2018b).

Selain permasalahan sosial ekonomi yang telah disebutkan di atas, beberapa masalah lain yang dihadapi Kecamatan Ledokombo dan Kecamatan Kalisat adalah permasalahan sumber air dan masalah sanitasi. Sejalan dengan penelitian yang dilakukan oleh Sakti bahwa masalah lingkungan berkontribusi terhadap masalah stunting (Sakti, 2020). Kecamatan Ledokombo dan Kalisat ini yang berdekatan ini secara umum mempunyai permasalahn serupa yakni masih banyak rumah tangga yang belum mempunyai akses terhadap sumber air minum yang terlindungi dan adanya rumah tangga yang tidak mempunyai fasilitas buang air besar yang layak.

Di Kecamatan Ledokombo terdapat 7.215 rumah tangga yang dengan sumber air minum tidak terlindungi, 14.075 rumah tangga tidak memiliki fasilitas buang air besar, dan 14.126 rumah tangga tidak menggunakan tangki septik, SPAL, dan lubang tanah. Untuk Kecamatan Kalisat masih ada 4.837 rumah tangga sumber air minum tidak terlindungi, dan 11.060 rumah tangga tidak memiliki fasilitas buang air besar, dan 12.199 rumah tangga tidak menggunakan tangki septik, SPAL dan lubang tanah (Tim Nasional Percepatan Penanggulangan Kemiskinan, 2017).

Permasalahan sanitasi ini secara spesifik ditemukan di desa-desa lokasi penelitian baik di Kecamatan Ledokombo maupu Kalisat. Berdasarkan temuan di lapangan dari beberapa informan bahwa tidak semua warga mempunya jamban sendiri, biasanya hanya ada kamar mandi sedangkan jika BAB atau mencuci, warga ada yang memanfaatkan sungai. Selain itu, ada juga informan yang mandi di jamban milik tetangga karena tidak memiliki fasilitas jamban sendiri. 
Di Desa Kalisat awalnya dulu ada jamban bersama namun kemudian ditutup oleh pemilik lahan karena kotor dan menganggap warga tidak punya kebiasaan menyiram dengan air setelah buang air besar sehingga bau dan membuat lingkungan tidak sehat. Karena itu beberapa warga yang tidak memiliki jamban akhirnya kembali ke sungai jika melakukan aktivitas MCK.

Di Desa Kalisat layanan kesehatan untuk menangani kasus stunting ini adalah di bidan desa dan posyandu. Akhir-akhir ini warga memiliki pemahaman yang lebih tentang gizi keluarga karena ada usaha dari kader-kader kesehatan. Hal ini dilakukan dengan strategi jemput bola, yakni kader kesehatan akan datang ke dusun-dusun yang jauh dari fasilitas kesehatan. Selain itu kader kesehatan juga aktif menginformasikan ke masyarakat untuk memeriksakan diri dan datang ke bidan jika ada masalah kesehatan pada anak balita mereka. Begitu pula tetangga di sekitar mereka juga berusaha mengingatkan jika ada posyandu atau pemeriksaan balita ke bidan.

Pelayanan kesehatan di Desa Ledokombo tidak jauh berbeda dengan Desa Kalisat. Pelayanan kesehatan dilakukan oleh bidan desa. Yang membedakan kalau di Desa Kalisat petugas lebih banyak mendatangi warga, sedangkan di Desa Ledokombo warga bisa datang langsung ke Poskesdes. Letak Poskesdes ini berdekatan dengan Kantor Desa. Harapannya dengan adanya Poskesdes ini memudahkan pemberian pelayanan kesehatan di desa, termasuk juga dalam pencegahan stunting. Keterlibatan pemerintah desa ini sesuai dengan adanya Peraturan Menteri Desa, Daerah Tertinggal dan Transimigrasi No 7 Tahun 2020 bahwa salah satu prioritas penggunanaan dana desa adalah untuk pencegahan stunting.

\section{Kebijakan Pemerintah Kabupaten Jember dalam Penanganan Stunting}

Pemerintah Kabupaten Jember sendiri telah berupaya dalam menyusun kebijakan, program, dan kegiatan bidang kesehatan yang merupakan dari perwujudan Misi II Kabupaten Jember yakni mewujudkan pemenuhan dasar masyarakat yang berkeadilan. Misi ini salah satunya bertujuan untuk meningkatkan derajat kesehatan masyarakat. Akan tetapi mengutip RPJMD Kabupaten Jember tahun 2016-2021, sasaran pembangunan kesehatan ini belum secara spesifik menjelaskan mengenai penanganan stunting itu sendiri. Sasaran yang disusun lebih mengarah pada 5 hal, antara lain: "sarana dan prasarana kesehatan termasuk tenaga medis dan non medis, penuruan $\mathrm{AKI}$ dan $\mathrm{AKB}$, kualitas pelayanan kesehatan, keterlibatan masyarakat dalam jaminan kesehatan, dan peningkatan akseptor KB". Meskipun tidak dijelaskan secara spesifik beberapa kebijakan yang telah ada tersebut merupakan bentuk kontribusi dalam penurunan stunting.

Adanya kenaikan stunting di Kabupaten Jember pada tahun 2019 ini kemudian Pemkab Jember segera mengambil langkah cepat yakni dengan dikeluarkannya Keputusan Bupati Jember Nomor 188.45/167/1.12/2019 tentang Daftar Balita Stunting Sebagai Penerima Bantuan Iuran Daerah (PBI-D0 di Kabupaten Jember Tahun 2019 dan Keputusan Bupati Jember Nomor 188.45/96/1.12/2019 tentang Tim Koordinasi Daerah Perencanaan Teknis Penanganan Balita Stunting Kabupaten Jember. Tim koordinasi ini mempunyai tugas, antara lain: pertama, melaksanakan upaya keterpaduan program/ kegiatan dan anggaran terkait dengan penurunan stunting melalui penerapan 8 Aksi integrasi intervensi gizi spesifik dan sensitif bagi keluarga sasaran prioritas. Kedua, mengkoordinasikan dan mengendalikan pelaksanaan tercapainya tiap aksi integrasi penanganan balita stunting. Ketiga, melaporkan hasil pelaksanaan tugas kepada Bupati dan Wakil Bupati Jember. 
Pembentukan Tim Koordinasi Daerah Perencanaan Teknis Penanganan Balita Stunting Kabupaten Jember ini juga sebagai bentuk pelaksanaan dari intervensi penurunan stunting terintegrasi kabupaten/kota yang dikomandani oleh Kementerian Perencanaan Pembangunan Nasional/ Badan Perencanaan dan Pembangunan Nasional. Melalui tugas tim koordinasi yang titik pentingnya pada penerapan 8 aksi terintegrasi. Adapun keberhasilan implementasi 8 aksi tersebut secara umum tergantung pada beberapa hal, misalnya validitas data jumlah stunting, kebijakan kabupaten/kota, efektivitas pelaksanaan program, dan kegiatan penurunan stunting serta kader kesehatan yang menangani masalah stunting.

Program lain yang telah dijalankan oleh Pemerintah Kabupaten Jember adalah mengadakan rembuk stunting yakni pada tanggal 13 September 2019 di Pendapa Wahyawibhawagraha. Hal ini sebagai bentuk dukungan dan komitmen dari Pemerintah Kabupaten Jember dalam melakukan percepatan pencegahan dan penurunan stunting. Melalui rembuk stunting ini juga sebagai bentuk dukungan dari lintas sektoral, lintas program, dan juga lintas masyarakat.

Sesuai dengan instruksi Kementerian Dalam Negeri Nomor 440 Tahun 2018 bahwa ada 10 lokasi yang menjadi pantauan pencegahan masalah bayi pendek. Lokasi tersebut antara lain: Desa Ngampelrejo, Purwoasri, Glagahwero, Cangkring, Tempurejo, Jelbuk, Patempuran, Gambiran, Sukogidri, dan Slateng. Hal ini kemudian diikuti dengan pelaksanaan bulan timbang September 2018, dan menambahkan 18 lokasi pantauan pencegahan masalah bayi pendek. Hal ini diperkuat dengan Keputusan Kemendagri bahwa ada 18 desa di Kabupaten Jember yang dijadikan lokus penanganan bayi pendek (Guntoro, 2019)

Pencegahan stunting melalui intervensi gizi yang terpadu, mencakup intervensi gizi spesifik, dan gizi sensitif. Intervensi gizi spesifik merupakan intervensi yang ditujukan kepada anak dalam 1.000 Hari Pertama Kehidupan (HPK). Kegiatan ini umumnya dilakukan oleh sektor kesehatan. Intervensi spesifik bersifat jangka pendek, hasilnya dapat dicatat dalam waktu relatif pendek. Kelompok sasaran dalam intervensi gizi spesifik ini mencakup ibu hamil, ibu yang sedang menyusui, anak usia 0 (nol) sampai 23 bulan, remaja, wanita usia subur (WUS), serta anak 24-59 bulan. Intervensi gizi sensitif merupakan intervensi yang ditujukan melalui berbagai kegiatan pembangunan di luar sektor kesehatan. Hal ini dilakukan melalui ketersediaan sarana air bersih dan air minum yang layak, akses sanitasi yang layak, meningkatknya pelayananan kesehatan baik dari kualitas maupun kuantitas, tercukupinya makanan bergizi untuk ibu dan anak, serta adanya perubahan mindset dan komitmen masyarakat dalam pola asuh anak.

Berdasarkan penjabaran kebijakan, program dan kegiatan di atas, Pemerintah Kabupaten Jember telah mengkolaborasikan antara kebijakan nasional dengan kebijakan daerah. Artinya Pemerintah Kabupaten Jember telah menjalankan kebijakan penurusan stunting dari pemerintah pusat/ kebijakan nasional dan diikuti dengan kebijakan dari Pemerintah Kabupaten Jember itu sendiri. Dalam pelaksanaan program dan kegiatan tersebut, diperlukan adanya kolaborasi antar OPD tidak hanya Dinas Kesehatan tetapi juga OPD terkait seperti Dinas PU, Dinas Pendidikan, dan Dinas Pemberdayaan Masyarakat dan Desa.

\section{Kesimpulan}

Berdasarkan hasil penelitian, dapat disimpulkan bahwa ada beberapa permasalahan sosial ekonomi yang dapat memengaruhi terjadinya stunting. Temuan kami adalah adanya 
praktek pernikahan dini, tingkat pendidikan yang rendah, serta masalah pekerjaan dan pendapatan menjadi pemicu terjadinya stunting. Masalah pekerjaan dan pendapatan dimana ratarata informan adalah sebagai buruh tani, yang untuk memenuhi kehidupan sehari-hari masih kurang. Masalah pekerjaan ini juga imbas dari pendidikan orang tua yang rendah sehingga kesulitan untuk mendapatkan lapangan pekerjaan.

Kondisi masyarakat di daerah yang terkena kasus stunting menunjukkan merupakan daerah yang berpendapatan rendah. Selain itu, terdapat pergeseran struktur pekerjaan pada desadesa yang mengalami stunting, dari masyarakat yang sebelumnya bekerja di sektor pertanianperkebunan menjadi sektor-sektor jasa seperti pertambangan, pekerja di pabrik, maupun menjadi TKI. Pergeseran struktur pekerjaan dari agrikultur ke non-agrikultur menjadikan sebagian masyarakat menjadi berkurang kemandiriannya dalam penyediaan makanan dan atau akses bahan makanan.

Pernikahan dini menjadi salah satu faktor penyebab ketidaksiapan orangtua dalam mengasuh anak. Ditambah minimnya pendidikan sehingga mereka tidak memahami pola asuh anak yang baik dan pemenuhan gizi anak menjadi tidak terpenuhi. Hal ini yang kemudian menyebabkan terjadinya stunting.

Pemerintah Kabupaten Jember telah berkomitmen dalam penanganan stunting. Hal ini terbukti dengan dikeluarkannya Keputusan Bupati Jember Nomor 188.45/167/1.12/2019 tentang Daftar Balita Stunting Sebagai Penerima Bantuan Iuran Daerah (PBI-) di Kabupaten Jember Tahun 2019 dan Keputusan Bupati Jember Nomor 188.45/96/1.12/2019 tentang Tim Koordinasi Daerah Perencanaan Teknis Penanganan Balita Stunting. Dalam implementasinya penanganan stunting ini juga bergantung pada bidan dan kader posyandu yang ada di masingmasing desa.

\section{Ucapan Terima Kasih}

Terima kasih kepada LPPM UB yang menyelenggarakan kompetisi Hibah Penelitian Pemula (HPP) pada tahun 2019. Karya ini merupakan bentuk luaran dari Penelitian HPP pada tahun 2019. Terima kasih juga disampaikan kepada Dinas Kesehatan, Bappeda, Kepala Bagian Tata Pemerintahan Pemkab Jember, Kecamatan, Puskesmas, Bidan, Pemerintah Desa Kalisat dan Desa Ledokombo, warga masyarakat sebagai informan di lokasi penelitian, yang telah bersedia diwawancarai oleh tim penulis dan telah memberikan beberapa dokumen berkaitan penelitian ini.

\section{Referensi}

Anselm, S., \& Juliet, C. (2013). Dasar-Dasar Penelitian Kualitatif. Yogyakarta: Pustaka Pelajar.

Azahari, A. (2000). Pembangunan Sumberdaya Manusia Dan Indeks Pembangunan Manusia Sektor Pertanian. Jurnal Ekonomi Dan Bisnis Indonesia, 15(1), 56-69.

BPS Kabupaten Jember. (2019). Profil Kemiskinan Kabupaten Jember.

Budiman, A. (1995). Pembangunan Dunia Ketiga. Jakarta: Gramedia Pustaka Utama.

Guntoro, H. (2019, September 14). Pemkab Jember Komitmen Atasi Stunting. Retrieved

October 9, 2020, from https://www.gesuri.id/pemerintahan/pemkab-jemberkomitmen-atasi-stunting-b1WmAZmAe 
Kemenkes RI. (2019). Kebijakan dan Strategi Penanggulangan Stunting di Indonesia (Vol. 2).

Retrieved from https://www.persi.or.id/images/2019/data/FINAL_PAPARAN_PERSI_22_FEB_20 19_Ir._Doddy.pdf

Kementerian Kesehatan Republik Indonesia. (2018a). Evaluasi Percepatan Penurunan Stunting. In Kementerian kesehatan. Retrieved from http://www.depkes.go.id/

Kementerian Kesehatan Republik Indonesia. (2018b). Situasi Balita Pendek (Stunting) di Indonesia. Pusat Data Dan Informasi Kementerian Kesehatan.

Kementerian Kesehatan RI Badan Penelitian dan Pengembangan Kesehatan Puslitbang Humaniora dan Manajemen Kesehatan. (2018). Hasil Utama Riskesdas 2018 Provinsi Jawa Timur. Retrieved from https://www.scribd.com/document/421851142/22033hasil-riskesdas-jatim-2018-pdf

Kriyantono, R. (2006). Teknik Praktis Riset komunikasi. In Kencana Prenada Media Group. Jakarta: Prenada Media.

Lidia, F. (2018). Hubungan BBLR dan ASI Ekslusif Dengan Kejadian Stunting di Puskesmas Lima Puluh Pekanbaru | Fitri | Jurnal Endurance: Kajian Ilmiah Problema Kesehatan. Jurnal Endurance Kajian Ilmiah Problema Kesehatan, 3(1).

Mayasari, D. I. (2019). Evaluasi Program Gerakan 1000 Hari Pertama Kelahiran (HPK) Dalam Pencegahan Stunting di Puskesmas Jelbuk Kabupaten Jember. Universitas Jember.

Moleong, L. J. (2009). Metodologi Penelitian. Bandung: Remaja Rosdakarya.

Moleong, L. J. (2013). Metodologi Penelitian Kualitatif. Bandung: PT Remaja Rosdakarya.

Nisa, L. S. (2018). Kebijakan Penanggulangan Stunting Di Indonesia. Jurnal Kebijakan Pembangunan, 13, 173-179.

Otterbach, S., \& Rogan, M. (2017). Spatial differences in stunting and household agricultural production in South Africa:(re)-examining the links using national panel survey data. Spatial Differences in Stunting and Household Agricultural Production in South Africa:(Re)-Examining the Links Using National Panel Survey Data, (11008). https://doi.org/10.21504/10962/59522

Pertiwi, D. F., \& Hariansyah, Muhammad Prasetya, P. E. (2019). Faktor Risiko Stunting Pada Balita Dikelurahan Mulyaharja Tahun 2019. PROMOTOR Jurnal Mahasiswa Kesehatan Masyarakat, 2(5).

Pratama, B., Angraini, D. I., \& Nisa, K. (2019). Penyebab Langsung (Immediate Cause) yang Mempengaruhi Kejadian Stunting pada Anak. Jurnal Ilmiah Kesehatan Sandi Husada, $10(2)$.

Probohastuti, N. F., \& Rengga, A. (2019). Implementation of Nutrition-Sensitive Interventions Policy for Stunting Decrease in Blora Regency | Probohastuti | Journal of Public Policy and Management Review. Journal of Public Policy and Management, 8(4).

Riduan. (2009). Metode dan Teknik Menyusun Proposal Penelitian. Bandung: Alfa Beta.

Sakti, S. A. (2020). Pengaruh Stunting pada Tumbuh Kembang Anak Periode Golden Age I Biormatika: Jurnal ilmiah fakultas keguruan dan ilmu pendidikan. Jurnal Ilmiah Fakultas Keguruan Dan Ilmu Pendidikan, 6(1).

Sugiyono. (2012). Metode Penelitian Kuantitatif dan Kualitatif. Jakarta: Alfabeta.

Syafrina, M., Masrul, \& Firdawati. (2019). Analisis Komitmen Pemerintah Kabupaten Padang 
Pariaman dalam Mengatasi Masalah Stunting Berdasarkan Nutrition Commitment Index 2018 | Syafrina | Jurnal Kesehatan Andalas. Jurnal Kesehatan Andalas, 8(2).

Tim Nasional Percepatan Penanggulangan Kemiskinan. (2017). 100 Kabupaten/Kota Prioritas untuk Intervensi Anak Kerdil (Stunting) (Vol. 2).

Umar, \& Haryanto, T. (2019). Kondisi Sosial Ekonomi Rumah Tangga dan Masalah Stunting Balita di Indonesia | Umar | Media Trend. Media Trend: Berkala Kajian Ekonomi Dan Studi Pembangunan, 14(1).

Usman, H., \& Akbar, P. S. (2009). Metodologi Penelitian Sosial. Jakarta: Bumi Aksara.

WHO. (2018). Reducing stunting in children: equity considerations for achieving the Global Nutrition Targets 2025. In Equity considerations for achieving the Global Nutrition Targets $2025 . \quad$ Retrieved from https://apps.who.int/iris/bitstream/handle/10665/260202/9789241513647eng.pdf?sequence $=1$

\section{Wawancara}

JH, Desa Ledokombo dan Desa Kalisat, 13 Oktober 2019

NY, Desa Ledokombo dan Desa Kalisat, 13 Oktober 2019 